\title{
Habitual diet in four populations of African origin: a descriptive paper on nutrient intakes in rural and urban Cameroon, Jamaica and Caribbean migrants in Britain
}

\author{
Louise I Mennen ${ }^{1, *}$, Maria Jackson ${ }^{2}$, Sangita Sharma ${ }^{3}$, Jean-Claude N Mbanya ${ }^{4}$, \\ Janet Cade ${ }^{3}$, Susan Walker ${ }^{2}$, Lisa Riste ${ }^{3}$, Rainford Wilks ${ }^{2}$, Terrence Forrester ${ }^{2}$, \\ Beverly Balkau ${ }^{1}$ and Kennedy Cruickshank ${ }^{3}$ \\ 'INSERM, Unit 258, 16 Avenue Paul Vaillant Couturier, F-94807 Villejuif Cedex, France: \\ ${ }^{2}$ Tropical Metabolism Research Unit, University of the West Indies, Mona Campus, Kingston 7, Jamaica: \\ ${ }^{3}$ Clinical Epidemiology Unit, Manchester University Medical School, Manchester M13 9PT, UK: \\ ${ }^{4}$ Department of Internal Medicine, University of Yaoundé I, Faculty of Medicine and Biomedical Sciences, BP 8046, \\ Yaoundé, Cameroon
}

Submitted 5 January 2000: Accepted 31 May 2000

\begin{abstract}
Background: The prevalence of chronic diseases is increasing in West Africa, the Caribbean and its migrants to Britain. This trend may be due to the transition in the habitual diet, with increasing (saturated) fat and decreasing fruit and vegetable intakes, both within and between countries.

Objective: We have tested this hypothesis by comparing habitual diet in four Africanorigin populations with a similar genetic background at different stages in this transition.

Design: The study populations included subjects from rural Cameroon $(n=743)$, urban Cameroon $(n=1042)$, Jamaica $(n=857)$ and African-Caribbeans in Manchester, UK $(n=243)$, all aged $25-74$ years. Habitual diet was assessed by a food-frequency questionnaire, specifically developed for each country separately. Results: Total energy intake was greatest in rural Cameroon and lowest in Manchester for all age/sex groups. A tendency towards the same pattern was seen for carbohydrates, protein and total fat intake. Saturated and polyunsaturated fat intake and alcohol intake were highest in rural Cameroon, and lowest in Jamaica, with the intakes in the UK lower than those in urban Cameroon. The percentage of energy from total fat was higher in rural and urban Cameroon than in Jamaica and the UK for all age/sex groups. The opposite was seen for percentage of energy from carbohydrate intake, the intake being highest in Jamaica and lowest in rural Cameroon. The percentage of energy from protein increased gradually from rural Cameroon to the UK.

Conclusions: These results do not support our hypothesis that carbohydrate intake increased, while (saturated) fat intake decreased, from rural Cameroon to the UK.
\end{abstract}

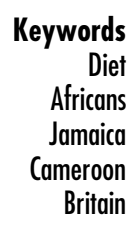

Lifestyle, and habitual diet in particular, is thought to have major influences on the risk of chronic disease, but most studies have been carried out in developed societies ${ }^{1}$. Cardiovascular disease and diabetes mellitus, diseases related to nutrition, are rapidly emerging in developing countries in West Africa ${ }^{2}$, and have already done so in the Caribbean $^{3-5}$ and especially in African-Caribbean migrants to Britain ${ }^{6,7}$ and the United States ${ }^{8}$. These populations share some genetic background, yet little is known about nutrient intakes, which may contribute to the geographic shift in cardiovascular risk in these people.
Atlantic slave trading led to the forced transport of over 12 million people from West Africa to the Caribbean and USA until the early nineteenth century. Details are scanty about dietary intakes of slaves and how intakes diversified in the different destinations over time ${ }^{9-12}$. In the Englishspeaking Caribbean, cultivation of root crop staples persisted, including different types of yams and cassava, while 'Irish' potatoes and rice were introduced later ${ }^{10}$. Local knowledge, market availability of foods and food manuals testify to the wide variety of fruit and vegetables available in the Caribbean and Cameroon. The migration 
of many Caribbean people to Britain and North America led to other changes in dietary habits with the availability of Western foods ${ }^{11,12}$. The main migration occurred during transition from colonial rule 30-50 years ago and the current population of older first-generation migrants and their descendants in Britain and the United States now exceeds the total population of adults in the Caribbean islands of origin.

The link between nutrient intakes and chronic diseases requires measurement of habitual diet, but few studies have measured nutritional intake in these African populations in any detail. We have developed specific food-frequency questionnaires for our international study on nutritional influences on the emergence of glucose intolerance and high blood pressure in four African-origin populations from Cameroon, Jamaica and the $\mathrm{UK}^{13}$. These questionnaires have now been applied to representative samples of subjects from these populations, providing data on the habitual dietary intake of macronutrients.

We hypothesised that a gradient exists in nutrient intakes, from rural to urban Cameroon, to Jamaica and to the UK, the diet carrying more cardiovascular risk (relatively more (saturated) fat and less carbohydrates) in the UK than in Jamaica and urban Cameroon, where nutritional 'risk' would again be higher than in rural Cameroon.

\section{Methods}

\section{Subjects}

Details of sampling methods by site have been published previously $^{2}$.

\section{Cameroon}

Cameroonian men and women of African origin, aged 24-74 years, were studied in an urban area, the Cité Verte Housing District in the capital Yaoundé, and in a rural area in Evodoula, Cameroon. The study was approved by the Ministry of Health's National Ethical Committee.

Three of the seven villages of the rural area of Evoduoula, Minwoho, Nkolassa and Nloudou, situated about $60 \mathrm{~km}$ from Yaoundé, were randomly selected as the rural sites. The occupation of the people of Evodoula is mainly farming and hunting. Four-hundred-and-thirtysix women and 307 men were included in the rural sample of the study, which is a response rate of $98 \%$.

The urban subjects, recruited from a housing estate, were mostly middle-grade civil servants or middle-income earners in the private sector. The response rate was 95\% and 584 women and 458 men were included in the urban sample.

\section{Jamaica}

The area around the old capital of Jamaica, Spanish Town, 15 miles from Kingston, the current capital, was identified to be representative of the island's rural as well as urban population by the Statistical Institute of Jamaica. The probability-proportional-to-size method was used to select enumeration districts of 100-400 households. House to house visits in selected districts recruited 512 women and 345 men, 25-74 years old, with a response rate of $60 \%$. The study was approved by the Ethics Committee of the University of the West Indies and informed consent was obtained from every participant.

\section{$U K$}

Random samples stratified by age decade and sex were taken from population registers in Manchester held in health centres serving the inner city wards where most African-Caribbeans live ${ }^{14}$. Initially any individual was eligible but later, as ethnicity is not identified on the registers and to increase numbers sampled, lists were scanned for names more likely to be African-Caribbean; all these people were invited and a random sub-sample of 1:3 others. Ethical permission was granted by the Central Manchester Health District Ethical Committee. In total 147 women and 96 men were included in the Manchester sample, a response rate of $80 \%$.

In Jamaica and the UK, African-Caribbean ethnicity was defined by at least three of four grandparents being of African descend and Caribbean origin. People of direct African origin or mixed descend were not included.

\section{Dietary assessment}

For each country a food-frequency questionnaire was developed to assess habitual nutrient intake during the previous 12 months and included those foods contributing at least $90 \%$ of total intakes of energy, fat,

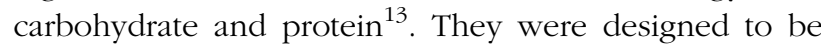
interviewer-administered and interviewers used local cooking utensils, specially prepared wooden food models and cutlery to help subjects to describe their own portion size. For Cameroon the questionnaire contained 76 different food items, and variations in consumption of foods between the wet and dry seasons was ascertained. The Jamaican questionnaire included 69 foods and drinks. The UK questionnaire included 108 Caribbean as well as European foods. To calculate the nutrient composition of the habitual diet, several food tables ${ }^{15-17}$ and Microdiet ${ }^{18}$ were used. Since these tables did not cover all the typical dishes eaten in Cameroon or by the African-Caribbean people, 45 dishes were prepared by local people in rural and urban Cameroon and 15 dishes by subjects from Manchester. All ingredients were weighed by trained field-workers, and the nutrient composition of the dishes was calculated.

The UK questionnaire was calibrated by comparison with a 24-hour recall and four-day weighed intake in a sub-sample of the total respondents. Spearman rank correlation coefficients ranged from 0.38 for protein to 0.62 for carbohydrate intake when compared with the four-day weighed intake, and from 0.38 for fat intake to 
Table 1 General characteristics of the female study population by site; mean (SD) or percentages

\begin{tabular}{lcccc}
\hline & Rural Cameroon & Urban Cameroon & Jamaica & Manchester \\
\hline$N$ Age (years) & 436 & 584 & 512 & $46(13)$ \\
Body mass index $\left(\mathrm{kg} \mathrm{m}^{-2}\right)$ & $46(13)$ & $38(9)$ & $27.6(6.4)$ & $48(13)$ \\
Education (\%) & $22.3(3.3)$ & $27.0(5.0)$ & 69 & $28.8(5.7)$ \\
$\quad$ Primary school or less & 89 & 18 & 23 & 5 \\
$\quad$ Secondary school & 9 & 42 & 8 & 23 \\
$\quad$ College or more & 3 & 40 & 45 & 58 \\
$\quad$ Marital status (\%) & 40 & 40 & 55 & 42 \\
$\quad$ Married/living together & 60 & 60 & & \\
\hline
\end{tabular}

0.50 for energy intake when compared with the 24-hour recall. When the food-frequency questionnaire was compared with the four-day weighed record, 39\% of subjects fell in identical quartiles, a further $44 \%$ were in adjacent quartiles and none were grossly misclassified. In Jamaica the reproducibility was tested in a sub-sample of 118 subjects who repeated the food-frequency questionnaire, and Pearson's correlation coefficients between protein, fat and carbohydrate intake from the first and second measurements were 0.62, 0.67 and 0.69, respectively (unpublished data; Jackson M, thesis, 1998).

\section{Data analyses}

Three age classes were used, 24-44 years (young), 45-59 years (middle-aged) and $\geq 60$ years (old), since food intake changes with age. Mean intakes of total energy and macronutrients were calculated by site and by age group, for men and women separately. The percentages of energy from macronutrients and saturated fat were calculated.

\section{Results}

The mean age was similar in rural Cameroon, Jamaica and the UK, but it was lower in urban Cameroon, for women as well as for men (Tables 1 and 2). The distribution of the level of education differed between the four sites, with the lowest level in rural and the highest in urban Cameroon. Caribbean migrant women had been in Britain a mean of 29 years ( $95 \%$ confidence interval (CI): 28, 30), while the men had been resident slightly longer, 31 years
(95\% CI: 29, 32). In the UK group, some $73 \%$ were of Jamaican origin and the remainder (in descending frequency) came from Barbados, St. Kitts, Montserrat and other eastern Caribbean territories.

In women, total energy intake was highest in rural Cameroon and lowest in the UK for all age groups (Table 3). The same pattern was seen for carbohydrates, protein and total fat intake. Saturated and polyunsaturated fat intake was also highest in rural Cameroon, but lowest in Jamaica, with the intakes in the UK being lower than those in urban Cameroon. The same trend was seen for alcohol intake, with very similar intakes in the UK and urban Cameroon. In men the trends in total energy and total fat intake paralleled those in women for the first two age classes (24-44 years and 45-59 years) (Table 4). In the age class over 60 years, intakes were highest in urban Cameroon, but this group comprised only nine men. The trends in intake of carbohydrates and protein differed somewhat from those seen in women. The intakes in Jamaica were higher than the intakes in urban Cameroon in the first age group, while they were highest in urban Cameroon in the second and third age groups. In men the intake of saturated and polyunsaturated fat was again lowest in Jamaica. Alcohol intake declined from rural Cameroon to the UK.

The percentages of energy from the macronutrients and saturated fat were calculated to compare macronutrient intake between sites, relative to total energy intake. The percentage of energy from total fat intake was higher in rural and urban Cameroon than in Jamaica and the UK for all age groups, in men as well as in women (Fig. 1). The

Table 2 General characteristics of the male study population by site; mean (SD) or percentages

\begin{tabular}{lcccc}
\hline & Rural Cameroon & Urban Cameroon & Jamaica & Manchester \\
\hline$n$ & 307 & 458 & 345 & 96 \\
Age (years) & $46(14)$ & $38(9)$ & $23)$ & $53(13)$ \\
Body mass index $\left(\mathrm{kg} \mathrm{m}^{-2}\right)$ & $21.9(2.7)$ & $25.0(3.7)$ & 65 & $27.1(3.3)$ \\
Education (\%) & 71 & 5 & 28 & 8 \\
$\quad$ Primary school or less & 24 & 27 & 7 & 22 \\
$\quad$ Secondary school & 5 & 68 & 39 & 39 \\
$\quad$ College or more & 23 & 36 & 71 & 62 \\
$\quad$ Marital status (\%) & 77 & 64 & & 2 \\
$\quad$ Singled/living together & & & & \\
\hline
\end{tabular}


Table 3 Energy and macronutrient intake of women by site and age group; mean ( $95 \% \mathrm{Cl})$

\begin{tabular}{|c|c|c|c|c|}
\hline Nutrients per age class & Rural Cameroon & Urban Cameroon & Jamaica & Manchester \\
\hline \multicolumn{5}{|l|}{$\overline{n(\%)}$} \\
\hline 24-44 years & $196(45)$ & $473(81)$ & $254(50)$ & \\
\hline $45-59$ years & $165(38)$ & 91 (16) & $161(31)$ & $63(43)$ \\
\hline$\geq 60$ years & 75 (17) & $20(3)$ & 97 (19) & $33(22)$ \\
\hline \multicolumn{5}{|l|}{ Energy (MJ) } \\
\hline $24-44$ years & $17.9(17.0,18.8)$ & $14.2(13.7,14.7)$ & $10.6(10.1,11.1)$ & $8.8(8.0,9.6)$ \\
\hline $45-59$ years & $15.6(14.6,16.6)$ & $13.9(12.8,15.0)$ & $9.3(8.7,9.9)$ & $7.7(6.9,8.5)$ \\
\hline$\geq 60$ years & $13.9(12.7,15.1)$ & $13.0(10.4,15.6)$ & $8.5(6.8,9.3)$ & $7.5(6.8,8.2)$ \\
\hline \multicolumn{5}{|l|}{ Carbohydrates (g) } \\
\hline 24-44 years & $485(461,509)$ & $417(401,433)$ & $378(358,398)$ & $287(263,311)$ \\
\hline $45-59$ years & $405(380,430)$ & $413(373,453)$ & $333(310,356)$ & $258(232,284)$ \\
\hline$\geq 60$ years & $386(351,421)$ & $363(282,444)$ & $305(276,334)$ & $250(226,274)$ \\
\hline \multicolumn{5}{|l|}{ Protein (g) } \\
\hline 24-44 years & $97(91,103)$ & $87(84,90)$ & $79(75,83)$ & $73(67,79)$ \\
\hline $45-59$ years & $85(79,91)$ & $83(77,89)$ & $75(68,82)$ & $67(61,73)$ \\
\hline$\geq 60$ years & $76(69,83)$ & $78(62,94)$ & $68(61,75)$ & $66(58,74)$ \\
\hline \multicolumn{5}{|l|}{ Total fat $(\mathrm{g})$} \\
\hline 24-44 years & $216(201,231)$ & $157(152,162)$ & $89(84,94)$ & $81(72,90)$ \\
\hline $45-59$ years & $192(176,208)$ & $153(141,165)$ & $76(70,82)$ & $66(57,75)$ \\
\hline$\geq 60$ years & $161(141,181)$ & $154(121,187)$ & $68(60,76)$ & $67(59,75)$ \\
\hline \multicolumn{5}{|l|}{ Saturated fat (g) } \\
\hline 24-44 years & $70(65,75)$ & $54(52,56)$ & $23(22,24)$ & $29(25,33)$ \\
\hline $45-59$ years & $62(56,68)$ & $52(48,56)$ & $20(18,22)$ & $24(20,28)$ \\
\hline$\geq 60$ years & $52(35,69)$ & $51(39,63)$ & $17(15,19)$ & $24(21,27)$ \\
\hline \multicolumn{5}{|l|}{ Polyunsaturated fat (g) } \\
\hline 24-44 years & $30(28,32)$ & $22(21,23)$ & $8.9(8.3,9.5)$ & $15(13,17)$ \\
\hline $45-59$ years & $27(25,29)$ & $22(20,24)$ & $7.4(6.7,8.1)$ & $12(11,13)$ \\
\hline$\geq 60$ years & $23(20,26)$ & $21(16,26)$ & $6.3(5.4,7.2)$ & $12(10,14)$ \\
\hline \multicolumn{5}{|l|}{ Alcohol (g) } \\
\hline 24-44 years & $13(11,15)$ & $4(3,5)$ & $1.1(0.7,1.5)$ & $4(3,5)$ \\
\hline $45-59$ years & $15(12,18)$ & $6(4,8)$ & $1.3(0.6,2.0)$ & $3(2,4)$ \\
\hline$\geq 60$ years & $13(9,17)$ & $4(0.7,7.3)$ & $0.4(0.07,0.73)$ & $2(1,3)$ \\
\hline
\end{tabular}

Table 4 Energy and macronutrient intake of men by site and age group; mean (95\% $\mathrm{Cl})$

\begin{tabular}{|c|c|c|c|c|}
\hline Nutrients per age class & Rural Cameroon & Urban Cameroon & Jamaica & Manchester \\
\hline \multicolumn{5}{|l|}{$\overline{n(\%)}$} \\
\hline 24-44 years & $153(50)$ & $358(78)$ & $178(52)$ & $26(27)$ \\
\hline $45-59$ years & $93(30)$ & $91(20)$ & $94(27)$ & 31 (32) \\
\hline$\geq 60$ years & $61(20)$ & $9(2)$ & $73(21)$ & $39(41)$ \\
\hline \multicolumn{5}{|l|}{ Energy (MJ) } \\
\hline $24-44$ years & $20.2(18.9,21.5)$ & $16.3(15.7,16.9)$ & $14.0(13.2,14.8)$ & $11.2(9.5,12.9)$ \\
\hline $45-59$ years & $17.0(15.6,18.4)$ & $16.1(14.9,17.3)$ & $11.6(10.6,12.6)$ & $9.7(8.3,11.1)$ \\
\hline$\geq 60$ years & $14.2(12.9,15.5)$ & $20.8(14.7,26.9)$ & $10.3(9.3,11.3)$ & $8.4(7.5,9.3)$ \\
\hline \multicolumn{5}{|l|}{ Carbohydrates (g) } \\
\hline $24-44$ years & $494(460,527)$ & $474(453,495)$ & $489(462,516)$ & $362(313,411)$ \\
\hline $45-59$ years & $443(403,483)$ & $438(398,478)$ & $404(368,440)$ & $324(277,371)$ \\
\hline$\geq 60$ years & $360(319,401)$ & $544(343,745)$ & $374(336,412)$ & $283(271,295)$ \\
\hline \multicolumn{5}{|l|}{ Protein $(\mathrm{g})$} \\
\hline $24-44$ years & $107(100,114)$ & $100(96,104)$ & $109(102,116)$ & $98(81,115)$ \\
\hline $45-59$ years & $86(77,95)$ & $100(93,107)$ & $96(87,105)$ & $85(73,97)$ \\
\hline$\geq 60$ years & $77(69,85)$ & $129(93,165)$ & $80(73,87)$ & $78(66,90)$ \\
\hline \multicolumn{5}{|l|}{ Total fat $(\mathrm{g})$} \\
\hline $24-44$ years & $244(223,265)$ & $177(170,184)$ & $121(113,129)$ & $105(85,125)$ \\
\hline $45-59$ years & $198(176,220)$ & $186(171,201)$ & $99(88,110)$ & $87(72,92)$ \\
\hline$\geq 60$ years & $173(149,198)$ & $251(185,317)$ & $82(73,91)$ & $73(61,85)$ \\
\hline \multicolumn{5}{|l|}{ Saturated fat $(\mathrm{g})$} \\
\hline $24-44$ years & $76(58,94)$ & $61(59,63)$ & $29(27,31)$ & $38(30,46)$ \\
\hline $45-59$ years & $61(53,69)$ & $65(59,71)$ & $24(21,27)$ & $30(25,35)$ \\
\hline$\geq 60$ years & $56(47,65)$ & $87(62,112)$ & $20(17,23)$ & $26(14,38)$ \\
\hline \multicolumn{5}{|l|}{ Polyunsaturated fat $(\mathrm{g})$} \\
\hline $24-44$ years & $32(30,34)$ & $25(24,26)$ & $15(14,16)$ & $18(15,21)$ \\
\hline $45-59$ years & $26(24,28)$ & $26(24,28)$ & $11(9,13)$ & $15(12,18)$ \\
\hline$\geq 60$ years & $24(21,27)$ & $36(26,46)$ & $9(8,10)$ & $13(11,15)$ \\
\hline \multicolumn{5}{|l|}{ Alcohol (g) } \\
\hline $24-44$ years & $47(37,57)$ & $13(11,15)$ & $10(7,13)$ & $7(2,12)$ \\
\hline $45-59$ years & $34(28,40)$ & $16(11,21)$ & $13(9,17)$ & $8(5,11)$ \\
\hline$\geq 60$ years & $22(18,26)$ & $16(3,29)$ & $5(2,8)$ & $7(4,10)$ \\
\hline
\end{tabular}




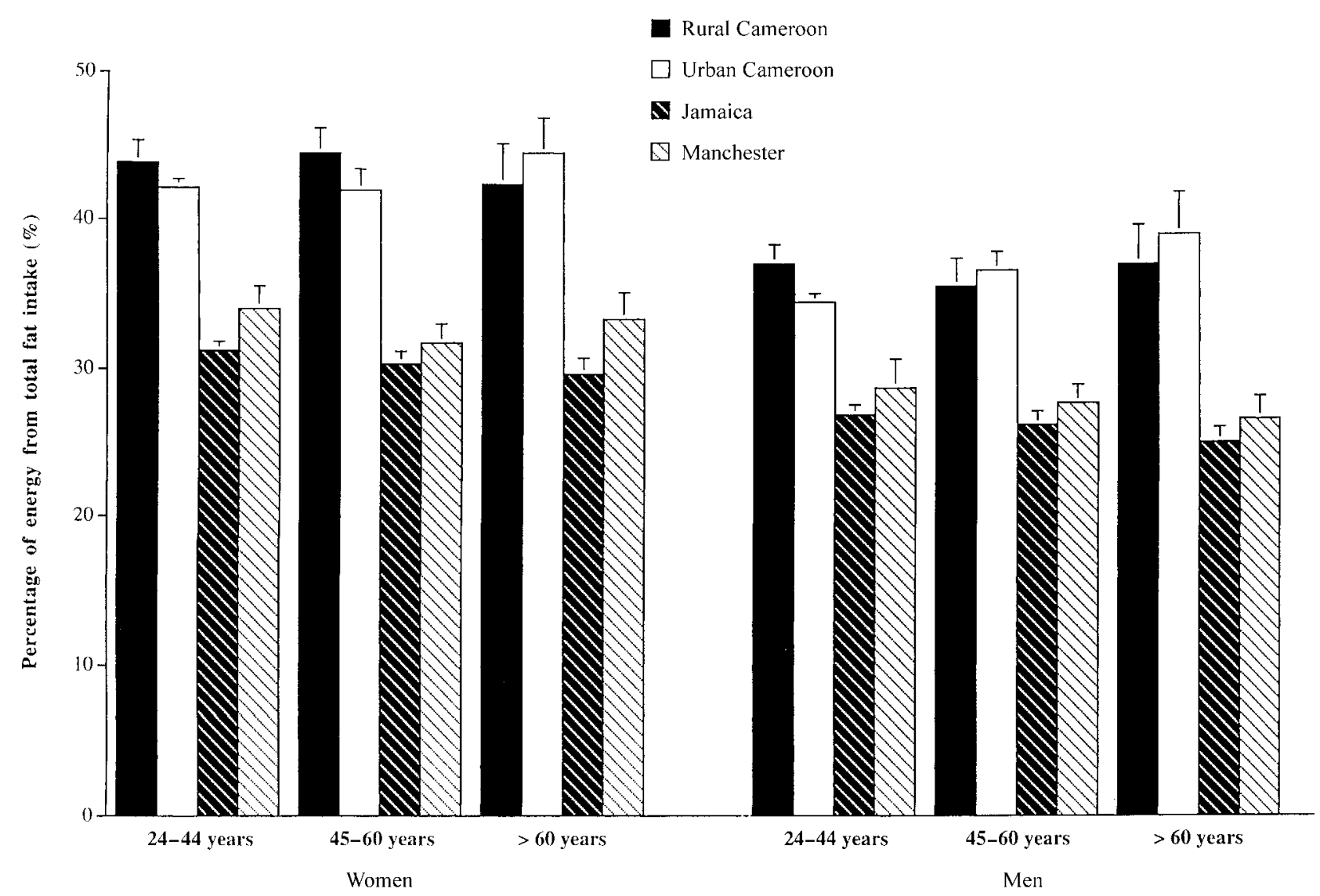

Fig. 1 Percentage of energy from total fat intake by age class and site; mean (upper $95 \%$ confidence limit)

lowest proportion of fat intake was always seen in Jamaica, while the highest was sometimes seen in rural and sometimes in urban Cameroon, depending on age group and gender. The opposite was seen for the percentage of energy from carbohydrate intake, with the highest intake in Jamaica and the lowest in rural Cameroon (Fig. 2). The percentage of energy from protein intake increased gradually from rural Cameroon to the UK (Fig. 3). This trend was seen for men and women in every age class. The percentage of energy from saturated fat intake was highest in urban Cameroon and lowest in Jamaica, with intermediate values in the UK and rural Cameroon (Fig. 4). In men aged 24-44 years there was no difference in saturated fat intake between rural and urban Cameroon.

\section{Discussion}

Absolute intakes of total energy and macronutrients were highest in rural Cameroon, and lowest in the UK, and the intakes in urban Cameroon were higher than in Jamaica. Intakes of total and saturated fat relative to the total energy intake were highest in rural and urban Cameroon, but lowest in Jamaica, while the percentage of energy from carbohydrates showed the opposite trend. The high (saturated) fat intake in Cameroon may be due to the frequent use of palm oil. Many of the traditional sauces and dishes contain large amounts of palm oil, the basic fat used in the Cameroonian kitchen. On the other hand we may have overestimated the amount of palm oil since calculation of nutrient composition from the recipes is difficult. Often whole palm nuts are used in preparation, but the fibrous pulp is partially discarded through cooking and the precise quantity of oil that has been extracted is unknown.

A limitation of this descriptive study is the limited number of subjects in the older age group in urban Cameroon. Although mean intakes were given by specific age group, the distribution of the subjects across these groups was different between urban Cameroon and the other sites. This has led to very few men in the highest age group in urban Cameroon $(n=9)$. These nine men are unlikely to be representative of men over 60 years of age living in urban Cameroon and therefore the data presented here for this particular age group should be interpreted with caution.

In this study, a food-frequency questionnaire was chosen to assess the habitual dietary intake, since a tool was needed which was easy to administer by 


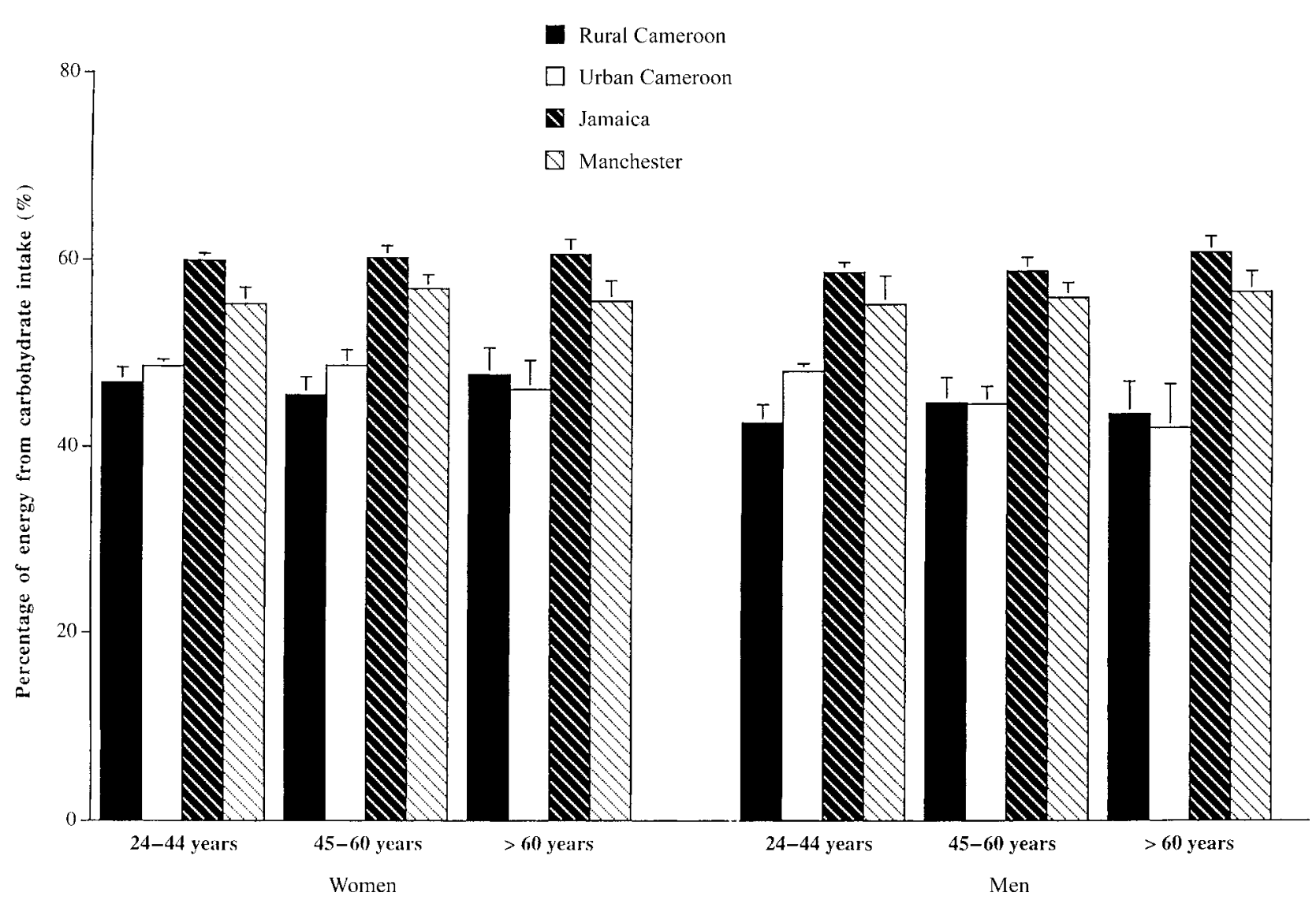

Fig. 2 Percentage of energy from carbohydrate intake by age class and site; mean (upper 95\% confidence limit)

non-nutritionists in each site in a large group of subjects. Food-frequency questionnaires are designed to measure long-term dietary intake and may therefore give a better approximation of the usual intake of a population than other methods ${ }^{19,20}$. Furthermore, they have been shown to categorise individual nutrient intakes adequately in epidemiological surveys ${ }^{21}$. Finally, weighed intake recordings are inappropriate in populations where people are not familiar with using scales during cooking. On these grounds, a food-frequency questionnaire seemed the best method to compare habitual diet across the four sites reported here.

Nutrient intakes of African-origin populations have not been studied in detail previously in any of the sites in this study. Our results did not confirm our hypothesis that a gradient exists across the four sites, with the lowest energy percentage of (saturated) fat and the highest energy percentage of carbohydrates in rural Cameroon and the opposite in the UK. In fact, the fat intake was highest in rural Cameroon, which may seem in conflict with the low current cardiovascular risk in that region. Although we did not have data on monounsaturated fat intake, it will probably make up most of the remaining fat, which is in fact the majority of the fat intake. Monounsaturated fats, which are an important component of the Mediterranean diet, have been recommended to replace saturated fat for cardiovascular disease prevention $^{22}$. In our study, although not measured directly, monounsaturated fat intake seems to be highest in rural Cameroon, and lowest in Manchester. The high intake of monounsaturated fat in rural Cameroon may counteract the high saturated fat intake at this site. Another explanation of our observations may be the difference in physical activity across sites. Most of the people living in rural Cameroon were farmers and were therefore engaged in strenuous physical activity, a cardioprotective factor not measured here ${ }^{23,24}$. Obviously this argument does not hold for the high energy and fat intake in urban Cameroon, although urban people often work periodically at rural farms and their physical activity may therefore be higher in general than people from Jamaica. Physical activity may thus explain the relation between nutrient intake and site, but the differences between Jamaica and the UK are in the expected direction, with a 'healthier' diet in Jamaica than in the UK.

In conclusion, the results of our study indicate that energy, and especially fat intake, in rural and urban Cameroon is higher than expected on the basis of the prevalence of chronic diseases, which can probably be explained by their regular strenuous physical activity. 


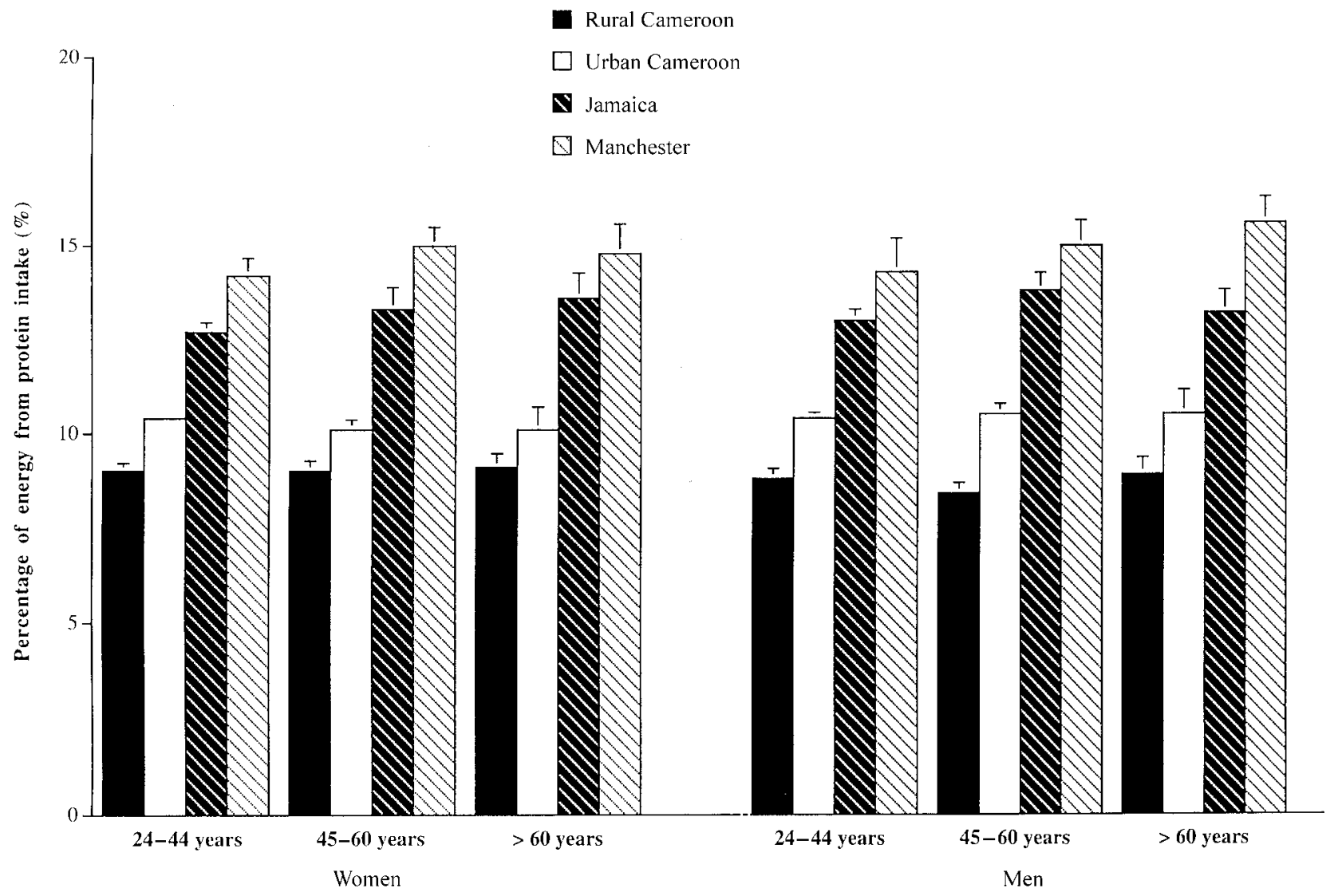

Fig. 3 Percentage of energy from protein intake by age class and site; mean (upper 95\% confidence limit)

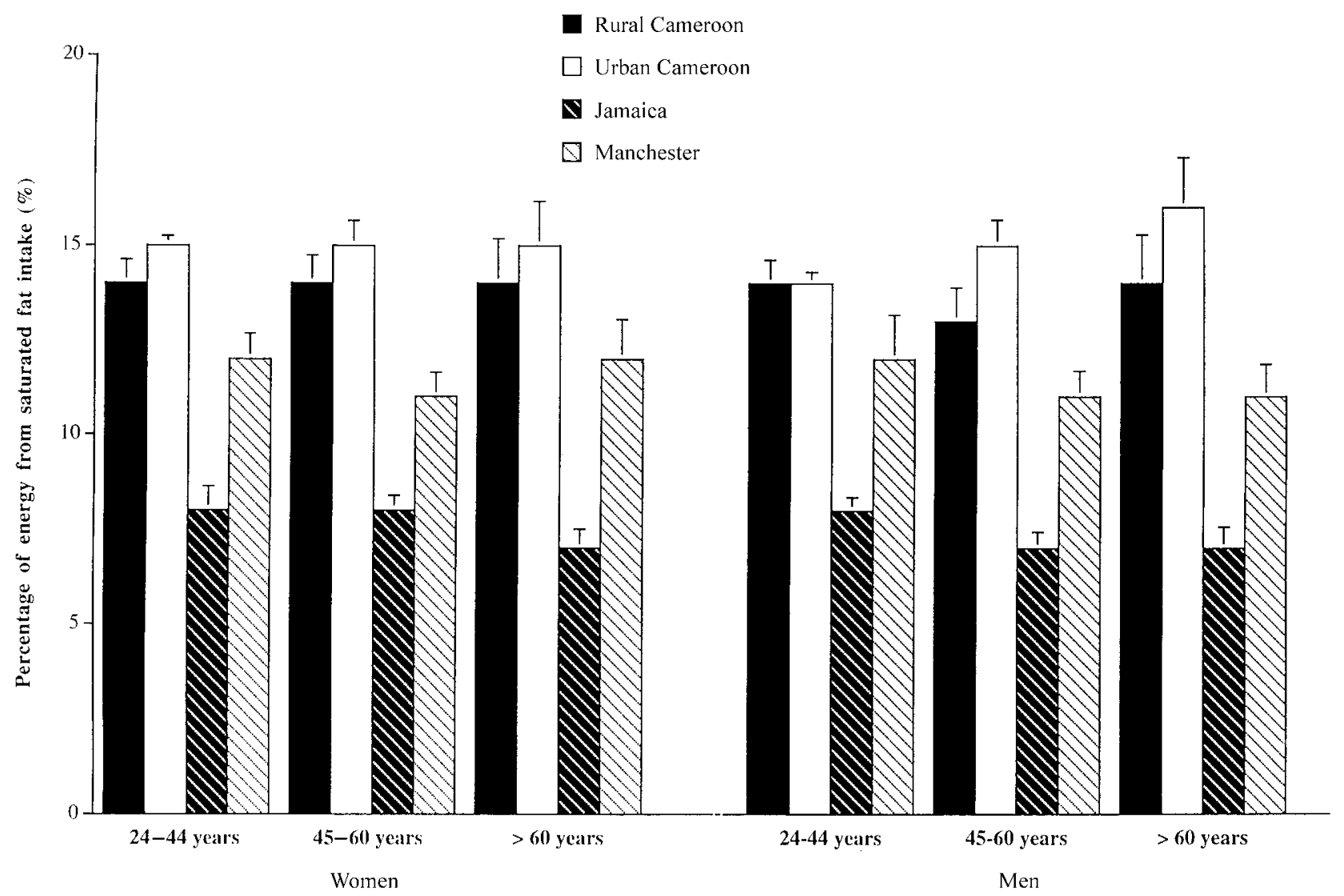

Fig. 4 Percentage of energy from saturated fat intake by age class and site; mean (upper 95\% confidence limit) 
These societies, however, are in transition and lifestyle may change in the near future. We should be aware of the fact that if the level of physical activity lowers, without changes in dietary habits, the risk of chronic disease will increase enormously in these societies. Prevention strategies should be focused on energy balance, a crucial factor in weight control. The changes and differences in food habits that we report from these four sites provide a unique opportunity to study the long-term health effects of dietary factors. More data are being collected for this study and further analyses will provide information on the relationship between habitual diet and chronic diseases, in particular hypertension and diabetes.

\section{Acknowledgements}

This work was supported by a grant from the European Union, contract N0 TS3*CT92-0142, and by the Conseil Régional d'Ile de France and INSERM for the postdoctoral position of Dr Mennen.

\section{References}

1 Stamler J. Assessing diets to improve world health: nutritional research on disease causation in populations. Am. J. Clin. Nutr. 1994; 59(Suppl.): 146S-56S.

2 Mbanya JCN, Ngogang J, Salah JN, Minkoulou E, Balkau B. Prevalence of NIDDM and impaired glucose tolerance in a rural and an urban population in Cameroon. Diabetologia 1997; 40: 824-9.

3 Alleyne SA, Cruickshank JK, Morrison E. Mortality from diabetes in Jamaica. PAHO Bull. 1989; 23: 306-15.

4 Ragoobirsingh D, Lewis-Fuller E, Morrison EYSA. The Jamaican Diabetes Survey. A protocol for the Caribbean. Diab. Care 1995; 18: 1277-9.

5 Grell GAC. Hypertension in the West Indies. Postgrad. Med.J. 1983; 59: 616-21.

6 Raleigh VS, Kiri V, Balarajan R. Variations in mortality from diabetes, hypertension and renal disease in England and Wales by country of birth. Health Trends $1997 ; \mathbf{2 8}$ : 122-7.

7 Cruickshank JK, Cooper J, Burnett M, MacDuff J, Drubra U. Ethnic differences in fasting plasma C-peptide and insulin in relation to glucose tolerance and blood pressure. Lancet 1991; 338: 842-7.

8 Fang J, Madhavan S, Alderman MH. The association between birthplace and mortality from cardiovascular causes among black and white residents of New York City. N. Engl. J. Med. 1996; 335: 1545-51.

9 Kiple K, Kiple V. Slave nutrition and disease during the $19^{\text {th }}$ century: the United States and the Caribbean. J. Interdisciplin. History 1980; 11: 197-215.

10 Beckles H, Shepherd V. Caribbean Slave Society and Economy. London Ian Randle Ltd Jamaica \& James Currey, 1991.

11 Blackburn R. The Making of New World Slavery. London/ New York, Verso, 1997; 1492-820.

12 Cruickshank JK, Beevers DG. Ethnic Factors in Health and Disease. London, Butterworth Heinemann, 1989.

13 Sharma S, Cade J, Jackson M, Mbanya JC, Chungong S, Forrester T, Bennett F, Wilks R, Balkau B, Cruickshank JK. Development of food frequency questionnaires in three population samples of African origin from Cameroon, Jamaica and Caribbean migrants to the UK. Eur. J. Clin. Nutr. 1996; 50: 479-86.

14 Sharma S, Cade J, Riste L, Cruickshank K. Nutrient intake trends among African-Caribbeans in Britain: a migrant population and its second generation. Public Health Nutr. 1999; 2: 469-76.

15 Holland B, Welch AA, Unwin ID, Buss DH, Southgate PAA. McCance and Widdowson's The Composition of Foods. London, The Royal Society of Chemistry, 1991.

16 Ngo Som J, Abono A. Les resources alimentaires $d u$ Cameroun: Répartition Ecologique, classification et valeur nutritive. Cameroon: SEPER, 1989.

17 Tan SP, Wenlock RW, Buss DH. Immigrant Foods: Second Supplement to McCance and Widdowson's The Composition of Foods. London, HMSO, 1985.

18 Fletcher L. Microdiet. Salford: University of Salford, 1994.

19 Willett WF, Sampson L, Stampfer MJ, Rosner B, Bain C, Witschi J, Hennekens CH, Speizer FE. Reproducibility and validity of a semiquantitative food frequency questionnaire. Am. J. Epidemiol. 1985; 122: 51-65.

20 Pietienen P, Hartman AM, Haapa E, Rasanen L, Haapakoski J, Palmgren H, Albanes D, Virtamo J, Huttunen JK. Reproducibility and validity of dietary assessment instruments II. A qualitative food frequency questionnaire. Am. J. Epidemiol. 1988; 128: 667-76.

21 Margetts BM, Cade J, Osmond C. Comparison of a food frequency questionnaire with a diet record. Int. J. Epidemiol. 1989; 18: 868-73.

22 Katan MB, Grundy SM, Willett WF. Beyond low-fat diets. $N$. Engl. J. Med. 1997; 337: 563-7.

23 Berlin JA, Colditz GA. A meta-analysis of physical activity in the prevention of coronary heart disease. Am. J. Epidemiol. 1990; 132: 612-28.

24 Blair SN, Kampert JB, Kohl HW, Barlow CE, Macera CA, Paffenbarger RS, Gibbons LW. Influences of cardiovascular fitness and other precursors on cardiovascular disease and all-cause mortality in men and women. JAMA 1996; 276: 204-10. 